\title{
Optimal composition of hybrid/blended real estate portfolios
}

Article

Accepted Version

Ametefe, F. K., Devaney, S. and Stevenson, S. A. (2019)

Optimal composition of hybrid/blended real estate portfolios. Journal of Property Investment \& Finance, 37 (1). pp. 20-41. ISSN 1463-578X doi: https://doi.org/10.1108/JPIF-04-20180022 Available at https://centaur.reading.ac.uk/78846/

It is advisable to refer to the publisher's version if you intend to cite from the work. See Guidance on citing.

To link to this article DOI: http://dx.doi.org/10.1108/JPIF-04-2018-0022

Publisher: Emerald Group Publishing Limited

All outputs in CentAUR are protected by Intellectual Property Rights law, including copyright law. Copyright and IPR is retained by the creators or other copyright holders. Terms and conditions for use of this material are defined in the End User Agreement.

\section{www.reading.ac.uk/centaur}

\section{CentAUR}

Central Archive at the University of Reading

Reading's research outputs online 


\title{
OPTIMAL COMPOSITION OF HYBRID/BLENDED REAL ESTATE PORTFOLIOS
}

\begin{abstract}
Purpose:

The purpose of this paper is to establish an optimum mix of liquid, publicly traded assets that may be added to a real estate portfolio, such as those held by open-ended funds, to provide the liquidity required by institutional investors such as UK defined contribution pension funds. This is with the objective of securing liquidity while not unduly compromising the risk-return characteristics of the underlying asset class. This paper considers the best mix of liquid assets at different thresholds for a liquid asset allocation, with the performance then evaluated against that of a direct real estate benchmark index.
\end{abstract}

Design/Methodology/Approach:

The authors employ a mean-tracking error optimisation approach in determining the optimal combination of liquid assets that can be added to a real estate fund portfolio. The returns of the optimised portfolios are compared to the returns for portfolios that employ the use of either cash or listed real estate alone as a liquidity buffer. Multivariate Generalised Autoregressive models are used along with rolling correlations and tracking errors to gauge the effectiveness of the various portfolios in tracking the performance of the benchmark index.

Findings:

The results indicate that applying formal optimisation techniques leads to a considerable improvement in the ability of the returns from blended real estate portfolios to track the underlying real estate market. This is the case at a number of different thresholds for the liquid asset allocation and in cases where a minimum return requirement is imposed.

Practical Implications:

The results suggest that real estate fund managers can realise the liquidity benefits of incorporating publicly traded assets into their portfolios without sacrificing the ability to deliver real estate-like returns. However, in order to do so, a wider range of liquid assets must be considered, not just cash.

Originality/value:

Despite their importance in the real estate investment industry, comparatively few studies have examined the structure and operation of open-ended real estate funds. To the authors' knowledge, this is the first study to analyse the optimal composition of liquid assets within blended or hybrid real estate portfolios.

Keywords: Real estate liquidity, tracking error, hybrid real estate, portfolio optimisation, blended real estate, defined contribution pensions

Article classification: Research paper 


\section{OPTIMAL COMPOSITION OF HYBRID/BLENDED REAL ESTATE PORTFOLIOS}

\section{Introduction}

Unlisted real estate funds are an important part of many mature property markets around the world and have grown significantly in number and assets under management in the last two decades. Yet, despite this, there is still relatively little academic research on such funds, either on their structure and operation or as an option for gaining exposure to real estate as an asset class. Open-ended funds, in particular, are a potentially attractive route for investors that desire exposure to a diversified pool of real estate investments while holding units that are reasonably liquid. However, the performance and liquidity of such funds has come into sharper focus in recent years. For instance, in the UK, the ability of investors to sell their holdings in some open-ended funds has been restricted following market shocks (Forbes, 2012; 2017).

This makes questions around the degree of liquidity that such funds can offer, and the means by which they can do so, important issues for research. Open-ended fund units are not normally traded on a secondary market. Instead, units are normally bought or sold directly from the fund itself. In order to facilitate such trades, openended funds typically hold significant amounts of cash in the portfolio, for which appendix A provides evidence in respect of UK funds. Yet cash acts as a drag on fund performance in most market conditions, reducing the returns achieved and thus the ability of the fund to match the performance of the underlying real estate market (Frodsham, 2012). While holding more cash enables a fund to redeem units more easily in downturns or following shocks, it also reduces its attractiveness to investors seeking real estate exposure.

In this context, this paper examines the implications of open-ended real estate funds holding different types of liquid assets in their portfolios alongside direct real estate. Such portfolios are called either blended or hybrid real estate portfolios, as they do not consist solely of direct real estate investments. Formal optimisation procedures are used to determine an optimal mix of liquid assets that might be held, with the aim of finding portfolios that replicate closely the performance of the underlying direct real estate market. The performance of these optimal portfolios is then compared to that of portfolios which use only a single predetermined liquid asset, such as cash, to provide the liquidity that is necessary for operation of the fund. The findings suggest that holding a mix of liquid assets could be more effective than holding cash in isolation.

This discussion does not imply that liquidity is a priority for all investors in real estate or even for all investors in open-ended real estate funds. For some investors in open-ended funds, restrictions on liquidity through minimum notice periods and exit fees are perceived to offer protection (Timmermans, 2009). Nonetheless, there has been increased emphasis on liquidity by numerous parties such as regulatory agencies, investment managers, pension trustees and consultants following the 2007-09 global financial crisis. At the same time, the low yield environment following the crisis has raised interest in real estate and other alternative asset classes as 
a means of meeting performance objectives. Thus, investors have been faced with the challenge of increasing their exposure to less liquid asset classes without sacrificing liquidity.

This paper contributes to the discussion of how real estate funds need to be structured to deal with the increased emphasis on liquidity while retaining the essential performance attributes of private real estate as an asset class. The goal is to add liquid, tradable assets to a direct real estate portfolio without altering the risk-return profile of the portfolio significantly. The paper begins by discussing literature on blended solutions in both real estate and other private asset markets before outlining the methods adopted to find optimal blended portfolios in a real estate context. The data used are then discussed before results and findings are presented, with the final section concluding on the implications of the findings and the areas for further research.

\section{Literature review}

Liquidity is a multifaceted concept for which a variety of proxy measures exist, none of which capture all of its dimensions (Ametefe et al., 2016). Here, liquidity refers to the ability of investors to buy or sell assets quickly, at low cost and with minimal loss in value from executing the trade. Liquidity is a relative concept, with private (direct) real estate investments seen as comparatively illiquid owing to their high transaction costs, lengthy and uncertain trading times, and low frequency of transactions. In the absence of active secondary markets, real estate funds that want to offer greater liquidity to investors must do so by holding other assets in addition to private real estate so that demands to exit the fund can be satisfied in a timely manner. This has been achieved traditionally by holding cash balances, but the use of public (or listed) real estate investments to facilitate greater liquidity has been explored by several studies.

\section{Blending direct and listed real estate investments}

Early studies into the benefits of including listed real estate in US direct real estate portfolios included Giliberto (1990), Giliberto and Testa (1990) and Stevenson (2001). These studies showed that there was potential to diversify by investing in both direct and listed real estate markets, with listed real estate assets acting as timing devices that enabled investors to observe market movements which take time to be reflected in private real estate values. Stevenson (2001) conducted sector level analysis using three REIT sectors - equity, mortgage and hybrid REITs - as well as non-US listed real estate assets. In addition to enhanced diversification, he noted that listed real estate made it possible for an investor to quickly alter the exposure of their portfolio, as well as infuse the portfolio with liquidity as an alternative to cash.

NAREIT (2011) also examined the benefits of blending private and listed real estate investments. They found that optimal blends of private real estate funds and listed real estate assets produced significantly better riskadjusted returns than investing in private vehicles alone. This was again driven by the diversification and timing 
benefits of listed real estate investments. They suggested that the optimal composition of blended real estate portfolios should be around one-third listed real estate and two-thirds private real estate. The optimal blended real estate portfolio was found to produce positive annual returns, with not a single period of negative return over the entire sample period, which remarkably encompassed the 2007-09 global financial crisis.

Lee (2014) analysed portfolios containing a blend of private and public real estate using the 70:30 allocation suggested by NAREIT (2011). His study employed the percent contribution to risk measure of Holman and West (2013) to see whether the additional return generated by including listed real estate justified the additional risk that it brought to the portfolio. The results showed that a blended public and private real estate portfolio produced a higher Sharpe ratio than any direct real estate fund type. However, listed real estate was found to be the main driver of volatility in the blended portfolios. Lee (2014) concluded that, although listed real estate enhanced the returns of blended portfolios, the benefits were not sufficient to justify the risk they contributed to the portfolio.

The findings of NAREIT (2011) were confirmed by Moss and Farrelly (2014). They analysed a 70:30 blend of UK unlisted real estate funds and global listed real estate funds over the period 1998-2013, as well as a portfolio split 70:25:5 between UK unlisted real estate, global listed real estate and cash. They found that adding global listed real estate to the portfolio resulted in return enhancement of about 19\% over the full period. It also led to a significant increase in volatility, though they found that the Sharpe ratio only declined modestly due to the high increase in returns. They argued that this decline was acceptable given the additional liquidity benefits that listed real estate provided. Meanwhile, the motivation for a cash allocation was to service the day-to-day liquidity requirements of the portfolio, so that the return enhancement benefits of listed real estate would not be lost through frequent trading of this element (see also Farrelly and Moss, 2014; Moss and Farrelly, 2015).

Nonetheless, although many asset managers are aware of the benefits of including some listed real estate in their direct real estate portfolios, Moss and Farrelly (2014) noted that most were reluctant to implement this strategy. One of the main concerns was the anticipated increase in tracking error. For example, allocating 30\% to listed real estate, as recommended by NAREIT (2011), resulted in a per-annum tracking error of $5.2 \%$ relative to the UK IPD direct real estate index. While listed real estate might offer a diversification benefit relative to direct real estate, if the aim in a multi-asset context is to obtain direct real estate returns, then adding listed real estate might be detrimental to that wider aim.

This raises the question of whether listed and direct real estate should be considered substitutes or complements from a multi-asset perspective, or whether listed real estate should simply be considered part of the broader equity market. The earliest studies to examine these questions utilised simple correlation based tests, which often revealed a low contemporaneous correlation between direct and listed real estate, and a high correlation between listed real estate and equities. More recent contributions have used cointegration and other advanced 
techniques to understand the linkages better. For instance, Ling and Naranjo (1999) examined whether the direct real estate and REIT markets in the US were integrated with the common equity market, but only REIT markets were found to be integrated. However, other studies have found evidence of integration between direct and listed real estate (for example, Wang et al., 1997; Tuluca et al., 2000; Morawski et al., 2008; Oikarinen et al., 2011). Most of these studies have found that returns in the listed real estate market lead direct real estate returns, implying that information is incorporated into the prices of listed real estate investments more quickly and that the two types of real estate will not track each other closely in the short-term as a result.

Hoesli and Oikarinen (2012) examined the short-term and long-term dynamics between listed and direct real estate. Their analysis was based on sector level data from Australia, the UK and USA, and they adjusted for the absence of leverage in direct real estate indexes. They showed that the returns of listed real estate were much closer to the direct real estate market than to the general stock market over the long run. Similarly, Yunus et al. (2012) found a long-term relationship between the listed and direct real estate markets, and that listed real estate leads the direct real estate market in the UK, US, Australia and Netherlands. Ang et al. (2013) studied the US market and found a common and highly persistent real estate cycle across both the direct and listed real estate markets. Both were broadly exposed to pro-cyclical market factors.

The foregoing suggests that direct and listed real estate might be good long-term substitutes, but, to the authors' knowledge, only Moss and Farrelly (2014; 2015) have considered the question of tracking error when combining direct and listed real estate into a blended portfolio, though low short-run correlations between direct and listed real estate imply that significant tracking error will be present. Meanwhile, none of the studies reviewed so far have addressed the question of which liquid assets beyond cash and listed real estate could be included within a blended real estate portfolio or the optimal combination of such assets. Given that many property funds have fixed, predetermined allocation to various liquid assets, sometimes with a tolerance level, this study considers the optimal mix of assets for the liquid asset component and examines the effects on returns, risk and tracking error in relation to a direct real estate benchmark.

\section{Replicating returns of illiquid assets - evidence from other markets}

The issue of enhancing liquidity within asset portfolios is not limited to the real estate market. O'Doherty et al. (2015) note a very high demand among institutional investors for passive replication products that track the performance of illiquid assets such as private equity and hedge funds. An example are Liquid Alternative Beta funds, which seek to replicate the risk and return characteristics of hedge fund indexes through investment in liquid, tradable instruments (see Drachman and Little, 2010). The use of factor models to replicate hedge fund performance is perhaps the most popular approach among product developers and academics (Hasanhodzic and Lo, 2007; Amenc, et al., 2008; Amenc et al., 2010; Bollen and Fisher, 2013). These models estimate the target fund or index exposure to certain factors and use the information to determine asset allocations within 
the replicated portfolios. For instance, Hasanhodzic and Lo (2007) constructed a factor model and used it to replicate the returns of 1,610 hedge funds. These funds covered all the major hedge fund investment strategies.

Factor models have some drawbacks that limit their effectiveness in replicating hedge fund returns. The lack of transparency in the investment process of hedge funds makes it difficult to identify an appropriate set of factors. This leads to poor out-of-sample performance of these models in tracking hedge fund returns, while products based on them have also been found to underperform the target portfolios (Amenc et al., 2010; Bollen and Fisher, 2013). Kat and Palaro (2005) advocate an alternative approach that does not seek to generate identical period-to-period returns, but generate returns with the same statistical properties as the hedge fund being replicated. Other alternatives to factor models are the algorithmic approach and the payoff distribution approach. O'Doherty et al. (2015) used an algorithm that combined information from several pre-selected models and applied this to create a cloned hedge fund.

Private equity funds are perhaps the most illiquid alternative asset class, as capital in these funds can be locked up for as long as twelve years (Timmermans, 2009). Nonetheless, such funds appeal to institutional investors as they can offer higher returns and diversification opportunities. A few studies have examined the possibility of replicating the risk and return features of private equity funds using more liquid investments. Axelson and Martinovic (2013) documented factors that determine the financial structure of private equity funds and compared these with publicly traded funds. Using factors identified in Axelson and Martinovic (2013), Stafford (2017) then explored the possibility of replicating private equity fund performance using a passive portfolio of similar public equity investments. A similar approach was taken by Ang et al. (2013), and MSCI has since created a liquid private equity index for US real estate investors based on their analysis.

\section{Approach}

Different strategies are employed in this study to create blended or hybrid real estate portfolios. The aim is to construct blended portfolios whose out-of-sample returns best replicate the risk and return features of the underlying direct real estate market over time. The types of blended portfolios constructed here are set out in Table I.

\section{INSERT TABLE I AROUND HERE}

The first strategy employs the use of cash as a liquidity buffer. This approach is referred to as Fund A (DRE$\mathrm{CASH}$ ) and is common among UK real estate funds as can be seen from Appendix A. The second strategy adds listed real estate to a portfolio of direct real estate investments. This is referred to as Fund B (DRE-LRE) and is used in funds such as Legal \& General's Pension Property Fund. Two further strategies are then examined 
using formal optimization procedures. In each case, portfolios are constructed by combining direct real estate with a selection of liquid assets; cash, listed real estate, aggregate stocks, and bonds of various maturities. The third strategy, referred to as Fund C (DRE-ALL), does not have a minimum return requirement, while the fourth strategy, labelled Fund D (DRE-ALL1), includes a requirement that the returns of the portfolio are at least equal to the average total return on the IPD UK real estate index over the same period.

For the first and second portfolios, once the proportion of cash or listed real estate to be included is determined, the blending process simply consists of adding this proportion to the direct real estate portfolio. The return of the blended portfolio can then be obtained from Equation 1 below:

$$
R_{p}=\left[r_{D R E}{ }^{*} w_{D R E}\right]+\left[r_{L A} w_{L A}\right]
$$

Where:

$\mathrm{R}_{p}=$ Return of the blended real estate portfolio

$r_{D R E}$ and $r_{L A}=$ return of direct real estate portfolio and selected liquid asset, respectively

$w_{D R E}$ and $w_{L A}=$ weight of direct real estate and selected liquid asset in the blended portfolio, respectively

For portfolios that include a wider selection of liquid assets, the optimal allocation to each liquid asset is determined using an extension of the mean-variance optimisation procedure of Markowitz (1952). The extension is made to accommodate the practice of evaluating the performance of managers relative to a benchmark (Rudd and Rosenberg, 1980; Roll, 1992; Rudolf et al., 1999). The optimisation problem is formulated in terms of excess return rates and their volatility as opposed to absolute return rates and their volatility. Tracking error is defined as the standard deviation of the difference between the portfolio returns and the benchmark return, and measures how closely returns for the blended portfolio follow the returns for the benchmark index. Mathematically:

$$
T E_{P}=\sigma\left(r_{P t}-r_{b t}\right)
$$

Another common approach to measuring the relationship between two variables is the correlation coefficient. However, tracking error is preferred here for the optimization procedure because the correlation coefficient is not a measure of congruence, but the strength of linear relationship. Thus, a high level of correlation is necessary but not a sufficient condition for minimising the tracking error variance of a portfolio. Given the variance of the portfolio returns and benchmark returns, as well as the correlation between a portfolio and the benchmark, the tracking error can be estimated using the relation below:

$$
T E_{P}=\left(\sigma_{P}^{2}+\sigma_{b}^{2}-2 \varrho \sigma_{p} \sigma_{b}\right)^{0.5}
$$

Where: 
$T E_{P}$ is the tracking error of a portfolio

$\sigma_{P}^{2}$ is the variance of portfolio returns

$\sigma_{b}^{2}$ is the variance of benchmark returns and

$\rho$ represents the correlation between the returns of the portfolio and the returns on the benchmark.

A general form of the tracking error optimisation model seeks to minimise the tracking error variance for a given expected excess return. The following numerical optimisation model is implemented:

Subject to:

$$
\min _{k} \sum_{k=1}^{T}\left(r_{\text {index }, t^{-}} \sum_{k=1}^{N} w_{k} r_{k, t}\right)^{2}
$$

$\sum_{t=1}^{T}\left(r_{\text {index }, t}-\sum_{k=1}^{N} w_{k} r_{k, t}\right)=0$

$\sum_{k=1}^{N} w_{k}=1$

$L<w_{k}<U$

Where:

$r_{\text {index,t }}=$ the return on the direct real estate benchmark at time $\mathrm{t}$

$r_{k, t}=$ the return on the $k$ th asset at time $t$

$w_{k}=$ the weight assigned to the kth asset

The optimizer selects a combination of assets that provides the lowest tracking error relative to the IPD UK index returns, subject to the constraints of zero expected tracking error, unit sum of weights and a set allocation to direct real estate. The weight set for direct real estate ranged from $0 \%$ to $90 \%$, in $10 \%$ intervals. The optimal combination of liquid assets was then determined for the remainder of the portfolio in each case. Discussion here focuses on four particular allocations to the liquid asset component. A 10\% weighting to liquid assets is discussed as this represents a typical allocation to liquid assets within UK open-ended real estate funds, while a $20 \%$ weight corresponds to the allocation by some existing hybrid funds such as the Legal \& General Hybrid Real Estate fund. A 50:50 portfolio is also presented for comparison, while a pure replication portfolio made up entirely of liquid assets is included to demonstrate the possibility of using liquid assets alone to proxy the direct real estate market.

Tracking error optimisation models are subject to limitations. As they minimise in-sample tracking error with respect to a benchmark, this could lead to over-fitting the data in-sample at the expense of additional out-ofsample tracking error. In-sample over-fitting may result in an unstable portfolio structure that requires frequent rebalancing and incurs significant transaction costs (Gregoriou et al., 2005). The models also make use of the covariance matrix, which means they suffer from the weaknesses generated by use of correlation as a measure of dependency. Correlation is a short-term statistic that lacks stability. Its estimation is sensitive to outliers, non-stationarity and volatility clustering. Some authors have suggested using vector autoregressive models to measure the relationship between variables. For example, Alexander and Dimitriu (2004) compared the classic 
mean tracking error (MTE) model with an enhanced MTE model that allowed for cointegration between the tracking portfolio and the index, but they found no clear advantages in using the enhanced MTE model.

Nonetheless, it has been shown that tail events exist where parameters such as correlation change drastically, so it is better to calculate a conditional correlation that estimates correlation based on all information available up to a particular time point. Several approaches can be used. A rolling correlation is easy to estimate and is capable of capturing time-variation and clustering of cross asset returns. However, there is no clear theoretical or empirical basis for selecting a window length. Furthermore, Anderson and Raimondo (2008) observed that, since all the observations in a rolling correlation analysis are given the same weight, it tends to adjust very slowly to new information. This problem increases with longer window lengths. Major changes in correlation estimates could occur when there are abnormally small or large return observations, especially when these observations enter or leave the window. Forbes and Rigobon (2002) found that rolling correlation coefficients are prone to bias. They explained that, as volatility increases in one asset market, heteroscedasticity in returns may cause the correlation coefficient to be biased upward (see also Chong et al., 2012).

To make up for these drawbacks, Engle (2002) suggested using the Dynamic Conditional Correlation (DCC) model. Many studies in the real estate literature have used this model (Cotter and Stevenson, 2007; Chong et al., 2009; Liow et al., 2009; Fei et al, 2010; Case et al., 2012; Heaney and Sriananthakumar, 2012; Sing and Tan; 2013). The DCC model calculates conditional correlations as a function of the past volatilities of assets and the covariance between them. Since all past information is used in the optimisation process, there is no difficulty in selecting a window length as with rolling correlations. Engle (2002) found that the multivariate and univariate volatility forecasts were consistent with each other and that the DCC models revealed important time varying features that might otherwise be difficult to quantify. The volatility forecasts and the correlations of the original assets remain unchanged when new variables are added to the system, depending on the way in which the model is revised.

The DCC model is estimated as a GARCH $(1,1)$ specification, employing the resulting standardized residuals to estimate the time varying correlation matrix. To accomplish this, the residuals are transformed by their estimated standard deviations $\Xi_{\mathrm{t}}={ }^{\varepsilon_{\mathrm{t}}} / \sqrt{\mathrm{h}_{\mathrm{t}}}$.

The covariance matrix can be expressed as $\mathrm{H}_{\mathrm{t}} \equiv \mathrm{D}_{\mathrm{t}} \mathrm{R}_{\mathrm{t}} \mathrm{D}_{\mathrm{t}}$, where $D_{t}$ is a diagonal matrix of univariate GARCH volatilities. $R_{t}=Q_{t}^{*-1} Q_{t} Q_{t}^{*-1}$ is the time varying correlation matrix, with $Q_{t}$ as described by:

$$
\mathrm{Q}_{\mathrm{t}}=(1-\mathrm{a}-\mathrm{b}) \overline{\mathrm{Q}}+\mathrm{a}\left(\Xi_{\mathrm{t}-1} \Xi_{\mathrm{t}-1}^{\prime}\right)+\mathrm{Q}_{\mathrm{t}-1}
$$

$\bar{Q}$ is the unconditional covariance of standardized residuals resulting from the first stage estimation, and $\mathrm{Q}_{t}^{*}$ is a diagonal matrix composed of the square root of the diagonal elements of $\mathrm{Q}_{\mathrm{t}}$. As with the standard GARCH 
$(1,1)$ model, the coefficients of the DCC $(1,1)$ model are estimated by maximum likelihood using the algorithm of Broyden-Fletcher-Goldfarb-Shanno (BFGS). Under the assumption of conditional multivariate normality, the log-likelihood function can be displayed as follows:

$$
L(\vartheta)=-\frac{1}{2}\left[\mathrm{TN} \ln (2 \pi)+\sum_{\mathrm{t}=1}^{\mathrm{T}} \ln \left|\mathrm{H}_{\mathrm{t}}+\Xi_{\mathrm{t}}^{\prime} \mathrm{H}_{\mathrm{t}}^{-1} \Xi_{\mathrm{t}}\right|\right]
$$

where $\Xi_{t}$ is an $N \times 1$ vector stochastic process, with $H_{t}=E_{t-1}\left(\Xi_{t} \Xi_{t}^{\prime}\right)$, being the $N \times N$ conditional variancecovariance matrix.

\section{Data}

UK data are used to analyse the effects of adding different combinations of liquid assets to a direct real estate portfolio over the period 1987 to 2015. Quarterly total return rates for direct real estate investments were sourced from MSCI IPD (splicing the IPD UK monthly index with the larger IPD UK quarterly index when the latter begins in Q1 2000), while total returns for listed real estate, government bonds, equities and cash were all sourced from DataStream. ${ }^{1}$ In-sample portfolios were estimated from Q1 1987, the earliest date from which quarterly return rates for direct real estate were available. Out-of-sample portfolios were estimated from the start of 1991, based on a five-year window. The first out-of-sample portfolio is estimated from Q1 1987 to Q1 1991, then the next is estimated by rolling the window forward by one quarter, and so on, repeating this process up to the second quarter of 2015. In total, 78 out-of-sample portfolios are estimated.

The direct real estate return series are appraisal based, which means that they tend to understate the risk of the underlying asset class. This leads, in turn, to an over-allocation to direct real estate in multi-asset optimisation studies (see Marcato and Key, 2007). In this study, the weight allocated to direct real estate has been set at particular thresholds and does not interfere with the relative allocation to different liquid assets in the portfolio. This is shown later by the results, as allocations within the liquid asset component remain stable, irrespective of the proportion allocated to direct real estate. However, the direct real estate index also serves as a benchmark against which the performance and tracking error of each portfolio is assessed, which is a potential limitation of the analysis conducted here.

Another criticism of direct real estate indexes concerns the difficulty in passively replicating their returns. The reason is the belief that an investor must hold a large number of properties to diversify unsystematic risk. For

\footnotetext{
${ }^{1}$ Note that the opportunity set has been limited to UK assets to avoid the added complications of currency fluctuations. This omission does not detract from the general points that the study seeks to make.
} 
example, while Callender et al. (2007) found that investing in 30 to 50 properties could achieve a large amount of risk reduction, they found that more properties were necessary to achieve very low levels of tracking error against the market index. However, their study was based on the use of naïve diversification, which ignores the gains from deliberate structuring of a portfolio to reduce systematic risk. Moreover, Boudry et al. (2013) have subsequently found that real estate portfolios do a good job of tracking index returns when these portfolios contain at least 20 assets.

The most common liquid assets in the portfolios of UK open-ended property funds are cash and listed real estate, but the liquid asset universe is expanded in this study to include the two main classes of liquid, publicly traded assets; bonds of various maturities and aggregate stocks. While many investors view the stable income flows of real estate to be bond-like, Shepard et al. (2015) found the long-run behaviour of real estate returns to be more equity-like, i.e. cyclical and growth sensitive. Thus, the role that both bonds and equities could play in replicating direct real estate returns is investigated. The FTSE all share index is used to represent the aggregate UK equity market, while return rates for bonds of various maturities are drawn from the Thomson Reuters DataStream bond indexes. The 3-month UK Treasury bill return is used as the proxy for cash.

Table II shows the quarterly return and risk characteristics of the various assets that are used to estimate optimal blended real estate portfolios. Listed real estate has the highest return and variability of all assets, while returns for shorter-term bonds are lower than those for longer-term bonds, implying an upward sloping yield curve for the majority of the period analysed. Concerning the relationship between direct real estate returns and other assets, the correlation coefficient between direct real estate and listed real estate is the highest, followed by that between direct real estate and stocks. It is interesting to note that the correlation between direct and listed real estate is far greater than the correlation between listed real estate and general stocks. Negative correlations are observed between direct real estate and all the bond series. The correlations between the various bond series are quite high, often more than 0.70 , while the correlation between cash and bonds is higher for shorter maturity than longer-maturity bonds.

\section{INSERT TABLE II AROUND HERE}

Although the correlation with listed real estate was the highest for all the selected liquid assets, due to the very high standard deviation, the tracking error with respect to direct real estate is very high. A high tracking error implies that, compared to the other liquid assets, the returns of listed real estate do not have a close association with the returns on the IPD direct real estate benchmark. This implies that adding general stocks or listed real estate to a blended real estate portfolio may result in a risk-return profile that is quite different from that of the real estate benchmark. In contrast, the tracking error of cash with respect to direct real estate was the lowest, implying that this may be the most suitable asset to be added to a blended real estate portfolio. 


\section{Results}

The optimal allocations for the blended real estate portfolios are now presented, looking first at the in-sample allocations and then the out-of-sample results. Funds A and B were made up of pre-determined allocations to direct real estate and either cash or listed real estate, with no optimization as per Moss and Farrelly (2014; 2015). Funds $\mathrm{C}$ and $\mathrm{D}$ were then constructed using the tracking error optimisation approach, with the aim of finding the combination of direct real estate and selected liquid assets that produces the lowest tracking error. Fund $\mathrm{C}$ had no minimum return constraint and Fund $\mathrm{D}$ was constrained to produce returns that matched the average total returns on the direct real estate benchmark.

\section{In-sample allocations, risk and returns of blended real estate portfolios}

The allocations from the in-sample optimization exercise were as follows. Without minimum return constraints, Table III shows that about $80 \%$ of the allocation to liquid assets in Fund $\mathrm{C}$ went to cash, while the remaining allocation was to listed real estate and to general equities. Although the reported proportions change in line with the overall allocation to liquid assets, once the allocations are rescaled to reflect only the liquid component, the mix of liquid assets remains constant. The allocation to cash remains at $80 \%$, while listed real estate and general stocks made up $12 \%$ and $8 \%$, respectively. The high allocation that cash receives is broadly in line with the investments made by existing UK open-ended real estate funds. However, the addition of some listed real estate and general stocks could still improve the tracking error of these portfolios relative to the direct real estate market.

\section{INSERT TABLE III AROUND HERE}

For Fund D, with a constraint that the returns of the portfolio should at least equal the average return of direct real estate, long-term bonds with maturities greater than 10 years gain significant allocations $33 \%$ of the liquid asset component). Again, the proportion of each liquid asset to the total liquid asset allocation is very consistent. The allocation to cash dropped from $80 \%$ to about $25 \%$ of the liquid asset component, while the allocation to general stocks increased from $8 \%$ to about $24 \%$, and listed real estate increased to $19 \%$. This suggests that, to remove the negative performance impact of the so called cash drag, other types of liquid assets are likely to be required within a blended real estate portfolio.

An examination of the returns of the various blended real estate funds presented in Table III shows that the in-sample tracking error of Fund C (DRE-ALL) was the lowest. This is followed by Fund A (DRE-CASH). However, the returns were also quite low when compared to the direct real estate index. For example, with just a $10 \%$ allocation to liquid assets, there is a drop in return from $2.31 \%$ to $2.22 \%$ per quarter for Fund $\mathrm{A}$ and 
2.25\% per quarter for Fund C. In contrast, although Fund B (a mix of direct and listed real estate) produced the highest tracking error, it generated consistently higher returns than the direct real estate index, matching the findings of Farrelly and Moss (2014) and NAREIT (2011). The in-sample returns of Fund D, which includes the minimum return constraint, were also higher than the return on the direct real estate index, but with a far lower tracking error than the portfolios where listed real estate was used in isolation.

The foregoing discussion indicates that cash is the most suitable standalone asset to be included in direct real estate portfolios to improve liquidity without significantly altering the risk-return profile. However, adding listed real estate and a small amount of general stocks represents the optimal strategy. This optimal strategy still leads to a loss in returns since the unconstrained portfolios contain a large amount of cash, so the cash drag remains. Thus, if concerned with return as well as tracking error, an investment manager may have to include long-term bonds, especially those with maturities longer than ten years. More would have to be invested in listed real estate and general equities as well. An investor must accept a slightly higher tracking error if they require returns that are closer to direct real estate returns.

\section{Out-of-sample allocations, risk and returns of blended real estate portfolios}

As noted earlier, the in-sample estimates from the tracking error optimisation model may be over-fitted, which could result in higher out-of-sample tracking errors. How well the model performs depends on whether outof-sample outcomes corroborate the in-sample results. Hence, the allocations and subsequent performance of blended real estate portfolios over different five year windows is examined. This also enables us to see whether the composition of the optimal portfolios remains stable across different windows or whether some rebalancing would be required.

As with the in-sample allocations, out-of-sample allocations to the various liquid asset classes remain similar, irrespective of the overall weight to liquid assets in the portfolio. This consistency implies that, once the optimal allocation is obtained, there is no need to re-run the allocation if the liquid asset weight is to be increased or decreased. All that is required is to rescale the allocations to individual liquid asset classes to reflect the new overall weight of liquid assets relative to direct real estate.

Figure 1 shows the liquid asset allocations within the blended real estate portfolios. The portfolios that have a $10 \%, 20 \%$ and $100 \%$ allocation to liquid assets are used as examples. The pattern of allocation remains the same irrespective of how much liquid asset is contained therein. The left hand panel of Figure 1 shows the results for the unconstrained optimal portfolios. The liquid component of these blended portfolios is invested heavily in cash, especially prior to 2007 . The only assets that had a significant allocation in the liquid component apart from cash is listed real estate. After 2007, though, general stocks and listed real estate together received allocations averaging about $40 \%$ of the liquid asset allocations. 


\section{INSERT FIGURE 1 AROUND HERE}

The right-hand panel of Figure 1 shows the allocation in the constrained optimal portfolios. These portfolios are more diversified than those in the left hand panel. The four assets that received significant allocations here are cash, listed real estate, general stocks and long-term bonds. Long-term bonds (10+ years) dominate the allocations between 1997 and 2003. Cash dominated the portfolio prior to 2000 and after 2007 but does not gain any allocation between 2000 and 2007. Short and medium term (3, 5 and 7 year) bonds also received allocations at various points within these portfolios.

Figure 2 shows the returns of the various blended real estate series alongside the returns on the IPD UK index. The returns of the blended Fund A (containing cash) and Fund C (unconstrained portfolio drawing on all liquid assets) track the benchmark more closely than their counterparts. This is also apparent from Table IV, where the tracking error reported for Fund C (DRE-ALL) is the lowest, followed by that of Fund A (DRE-CASH). The tracking error per quarter for Fund C ranges from $0.29 \%$ with only $10 \%$ weighting to liquid assets to $2.90 \%$ for the portfolio that contains only liquid, publicly traded assets. For Fund A, the tracking error ranges from $0.32 \%$ to $3.16 \%$.

\section{INSERT FIGURE 2 AROUND HERE}

\section{INSERT TABLE IV AROUND HERE}

The combination of listed and direct real estate (Fund B) exhibits the highest tracking errors. This is consistent across all levels of liquid asset allocation. With only $10 \%$ allocated to listed real estate, the tracking error for Fund B is $1.06 \%$. This increases to $10.56 \%$ tracking error per quarter where only listed real estate is held. Imposing a minimum return requirement on the tracking error model also increases the tracking error, but not by as much as for a purely listed and direct real estate mix. For Fund D, the tracking error ranged from 2.64\% to $8.82 \%$.

Table IV shows that, of the different blended portfolios, the only one that recorded return enhancement when the allocation to liquid assets increased was Fund B. In contrast, the returns for Funds A, C and D fall with every increase in the liquid asset allocation. There are differences when compound growth is considered instead of arithmetic average return rate. This shows that using listed real estate alone only enhanced returns up to a certain threshold. This was due largely to the volatility in listed real estate returns. Listed real estate also has the highest drawdown - a measure of risk which indicates how much an investment value would fall from peakto-trough until a new maximum is reached. Consequently, portfolios for Fund B recorded the highest standard deviations among all the portfolios constructed.

Table VI shows that as much as 53\% can be lost by substituting direct real estate for cash. This means that the lower tracking error observed earlier for the blended portfolio containing cash often comes at the cost of 
significant losses in return. The challenge then is to find a way of reducing tracking error without sacrificing significant returns. Including a wider selection of liquid assets and employing the MTE optimisation procedure results in lower tracking error than simply adding cash to a direct real estate portfolio. From Table IV, it can be seen that Fund $C$ produced lower tracking errors than Fund A, while providing returns that were higher. In the case of Fund D, unlike the in-sample results, which were subject to the minimum return constraint, the outof-sample returns fell short of the IPD benchmark. This notwithstanding, the returns obtained from Fund D were higher and closer to direct real estate returns than those for Fund C. Yet tracking error increased slightly with the imposition of the minimum return constraint.

\section{Analysis of the time varying relationship between bybrid fund returns and direct real estate}

To account for potential temporal instability in relationships, rolling tracking errors are estimated using a 20quarter (five year) window. As can be seen from Figure 3, the Portfolio containing direct real estate and listed real estate consistently had the highest tracking error relative to the direct real estate benchmark. This confirms the results of previous studies and concerns raised by industry practitioners regarding the incorporation of listed real estate within blended portfolios, as well as the results of the static tracking error analysis presented earlier. The best combinations remain cash and the blended real estate Fund $C$ that contains all liquid assets.

\section{INSERT FIGURE 3 AROUND HERE}

Tracking error increased for all the blended real estate funds in the periods around the Global Financial Crisis (2007 - 2009). Fund C (optimisation using all liquid assets) recorded the lowest tracking errors, which ranged from a minimum of $0.0162 \%$ per quarter (containing a 10\% allocation to liquid assets) to a maximum of 5.4733 per quarter (for the pure replication fund). This compares to a minimum of $0.0695 \%$ to a maximum of $22.49 \%$ tracking error for Fund B (listed and direct real estate mix). Funds A and D recorded a range in tracking error of $0.0256 \%$ to $8.29 \%$ and $0.0256 \%$ to $6.92 \%$, respectively.

Different estimates of correlation are presented in Table V. The average dynamic conditional correlation was identical to the 20 quarter rolling correlation for most funds. As in Chung et al. (2012) and Forbes and Rigobon (2002), where there were differences, the average conditional correlation was typically lower than the average rolling correlation. At lower levels of direct real estate allocation, the correlations between the return rates for the blended portfolios and those of the benchmark were low and even negative at times. However, when the allocation to direct real estate is increased, the correlations increase markedly. Returns for Fund A typically had a higher correlation to direct real estate than all the other funds. This is attributable to the very low volatility of cash, which makes it less likely to significantly alter the return pattern of the direct real estate portfolio when added into the mix.

\section{INSERT TABLE V AROUND HERE}


Interestingly, fund B (DRE-LRE) recorded a very stable correlation pattern relative to direct real estate. Even for the pure replication portfolio, containing no direct real estate, the correlation coefficients were above 0.45 over the entire sample period. This is due to the fact that, as a stand-alone asset, listed real estate had a high correlation with direct real estate. Consequently, blended portfolios containing listed real estate show a stable correlation pattern with direct real estate. What this result implies is that, for investors who wish to have real estate portfolios that have significant allocations to liquid assets, especially more than $50 \%$, listed real estate may represent a better choice of asset than any other stand-alone asset. Yet it is clear from the foregoing discussion that a multi-asset approach to the liquid asset element is best at producing the best blended or hybrid real estate portfolios.

\section{Conclusion}

Managers of open-ended real estate funds have typically used cash, and sometimes listed real estate, to enhance the liquidity profile of their portfolios. Focus on the performance and liquidity of such funds has increased in recent years in the wake of market shocks and with the increased emphasis on liquidity by institutional investors. This includes the rising number of Defined Contribution pension funds, which have been offering daily traded investment funds to their contributors as opposed to monthly or even quarterly traded funds. In turn, this raises the question as to whether private real estate and other alternative asset classes are possible options in such a framework.

The inclusion of listed real estate in blended real estate portfolios has been found to enhance the returns of such portfolios, while providing liquidity. However, many investment managers are reluctant to use listed real estate investments within real estate portfolios owing to the fact that its inclusion can result in a high tracking error relative to a direct real estate benchmark, implying that the resulting portfolio fails to provide investors with property-like returns. Yet the use of cash to provide liquidity can result in significant drags on portfolio performance. The challenge for real estate funds is to find a way of minimising tracking error with the direct real estate market without significant loss of returns or alteration to the fundamental performance features of direct real estate assets.

This paper explores the expansion of the asset universe beyond cash and listed real estate to see if it is possible to produce portfolios that deliver property-like returns along with enhanced liquidity. As well as cash and listed real estate, general stocks and bonds of various maturities were used as options for addition to direct real estate portfolios. To create the blended portfolios, Minimum Tracking Error optimisation procedures were used. This procedure is an extension of the classic Mean-Variance optimisation procedure and was implemented both with and without a minimum return constraint in order to observe the most effective combinations of liquid assets in meeting portfolio objectives. 
The results showed that using a wider array of assets for the liquid asset element led to blended portfolios with lower tracking errors than those obtained by using a cash-only liquidity buffer. Not only that, but the returns obtained were higher than those from a direct real estate and cash-only mix. In comparison, the returns of the direct real estate and listed real estate combination did not perform well in replicating the underlying direct real estate market. As in other studies, the direct-listed real estate combination produced enhanced returns, but this study shows that the terminal value obtained over the period for this strategy was lower if a certain threshold allocation to listed real estate was crossed. This is due to the high volatility and drawdown of listed real estate as a stand-alone asset.

One key question which this paper seeks to answer is which assets should be included in the blended/hybrid real estate portfolio. The answer depends on whether the fund manager is concerned solely with tracking direct real estate returns as closely as possible or is also concerned with earning returns that are not significantly lower than direct real estate returns. A pure, unconstrained tracking error minimization portfolio consists largely of cash along with a limited amount of listed real estate and general stocks. The dominance of cash in this portfolio lends some credence to the current allocation to cash within UK open-ended real estate funds. Imposing a minimum return constraint, where the portfolio must at least match the average return of the direct market, resulted in a more diversified portfolio overall, with cash playing a limited role. These constrained portfolios had significant allocations to long term bonds, listed real estate and general stocks.

A number of future studies could be conducted in this area. The asset universe could be expanded further to include non-UK real estate and liquid assets. This would result in additional challenges stemming from foreign exchange risk and the difficulty in finding foreign assets that can be incorporated without significantly changing the risk and return profile of the portfolio. Factor models, as used in hedge fund and private equity markets, could also be explored to determine how direct real estate returns might be replicated to enable investors take advantage of the benefits of direct real estate investments with minimal liquidity risk. Finally, this study used historical returns in the estimation of the portfolio weights, so another area that could be explored is the use of forward looking risk and return measures in the construction of the blended real estate portfolios.

\section{Appendix A}

INSERT APPENDIX A HERE

\section{References}

Alexander, C. \& Dimitriu, A. (2004), The art of investing in hedge funds: Fund selection and optimal allocations. Retrieved from: https://papers.ssrn.com/sol3/papers.cfm?abstract id=494404 [Accessed March 2018] 
Amenc, N., Géhin, W., Martellini, L. \& Meyfredi, J. C. (2008), "Passive hedge fund replication: A critical assessment of existing techniques", Journal of Alternative Investments, Vol. 11, No. 2, pp. 69-83.

Amenc, N., Martellini, L., Meyfredi, J. C. \& Ziemann, V. (2010), "Passive hedge fund replication - Beyond the linear case”, European Financial Management, Vol. 16, No. 2, pp. 191-210.

Ametefe, F., Devaney, S. \& Marcato, G. (2016), "Liquidity: A Review of Dimensions, Causes, Measures, and Empirical Applications in Real Estate Markets", Journal of Real Estate Literature, Vol. 24, No. 1, pp. 1-29.

Anderson, R. M. \& Raimondo, R. C. (2008), "Equilibrium in Continuous-Time Financial Markets: Endogenously Dynamically Complete Markets”, Econometrica, Vol. 76, No. 4, pp. 841-907.

Ang, A., Nabar, N. \& Wald, S. J. (2013), "Searching for a common factor in public and private real estate returns", Journal of Portfolio Management, Vol. 39, No. 5, 120-133.

Axelson, U. \& Martinovic, M. (2013), European venture capital: myths and facts, London: British Private Equity \& Venture Capital Association.

Bollen N. \& Fisher G. (2013), "Send in the Clones? Hedge Fund Replication with Futures Contracts", Joumal of Alternative Investments, Vol. 16, No. 2, pp. 80-95.

Boudry, W. I., Coulson, N. E., Kallberg, J. G. \& Liu, C. H. (2013), “On Indexing Commercial Real Estate Properties and Portfolios", Journal of Real Estate Finance and Economics, Vol. 47, No. 4, pp. 617-639.

Callender, M., Devaney, S., Sheahan, A. \& Key, T. (2007), "Risk reduction and diversification in UK commercial property portfolios”, Journal of Property Research, Vol. 24, No. 4, pp. 355-375.

Case, B., Yang, Y. \& Yildirim, Y. (2012), "Dynamic correlations among asset classes: REIT and stock returns", Journal of Real Estate Finance and Economics, Vol. 44, No. 3, pp. 298-318.

Chong, J., Miffre, J. \& Stevenson, S. (2009), “Conditional correlations and real estate investment trusts”, Journal of Real Estate Portfolio Management, Vol. 15, No. 2, pp. 173-184.

Chong, J., Krystalogianni, A. \& Stevenson, S. (2012), "Dynamic correlations between REIT sub-sectors and the implications for diversification”, Applied Financial Economics, Vol. 22, No. 13, pp. 1089-1109.

Cotter, J. \& Stevenson, S. (2007), "Uncovering volatility dynamics in daily REIT returns", Joumal of Real Estate Portfolio Management, Vol. 13, No. 2, pp. 119-128.

Drachman, J. \& Little, P. (2010) Enhancing Liquidity in Alternative Portfolios, Credit Suisse: www.creditsuisse.com/pwp/am/downloads/marketing/tl_201006_lab_us_apac_jp_ie_lux_sp_scand uk_pdf

[Accessed March 2018]

Engle, R. (2002), "Dynamic conditional correlation: A simple class of multivariate generalized autoregressive conditional heteroskedasticity models", Journal of Business \& Economic Statistics, Vol. 20, No. 3, pp. 339-350.

Farrelly, K. \& Moss, A. (2014). "Blending Public and Private Real Estate Allocations for Defined Contribution Pension Funds: A UK Case Study”, Journal of Real Estate Porffolio Management, Vol. 20, No. 3, pp. 137-150.

Fei, P., Ding, L. \& Deng, Y. (2010), "Correlation and volatility dynamics in REIT returns: performance and portfolio considerations”, Journal of Portfolio Management, Vol. 36, No. 2, 113-125.

Forbes, J. (2012), Unlisted funds - Lessons from the crisis, Report for The Association of Real Estate Funds, PricewaterhouseCoopers LLP. 
Forbes, J. (2017), A review of real estate fund behaviour following the EU referendum, Report for The Association of Real Estate Funds. John Forbes Consulting LLP.

Forbes, K. J. \& Rigobon, R. (2002), "No contagion, only interdependence: measuring stock market comovements", The Journal of Finance, Vol. 57, No. 5, pp. 2223-2261.

Frodsham, M. (2012), A decade of fund returns, London: Investment Property Forum.

Giliberto, M. (1990), Global RealEstate Securities: Index Performance and Diversified Portfolios, Salomon Brothers Bond Market Research, February, pp. 1-9.

Giliberto, M. \& Testa, B. (1990), Global Property Share Performance by Geographic Region, Salomon Brothers Bond Market Research, August, pp. 1-6.

Gregoriou, G. N., Sedzro, K. \& Zhu, J. (2005), "Hedge fund performance appraisal using data envelopment analysis", European Journal of Operational Research, Vol. 164, No. 2, pp. 555-571.

Hasanhodzic, J. \& Lo, A. W. (2007), "Can hedge-fund returns be replicated? The linear case”, Journal of Investment Management, Vol. 5, No. 2, pp. 5-45.

Heaney, R. \& Sriananthakumar, S. (2012), “Time-varying correlation between stock market returns and real estate returns", Journal of Empirical Finance, Vol. 19, No. 4, pp. 583-594.

Hoesli, M. \& Oikarinen, E. (2012), "Are REITs real estate? Evidence from international sector level data", Journal of International Money and Finance, Vol. 31, No. 7, pp. 1823-1850.

Holman, J. and West, K. (2013), “A ‘Required Return’ Framework is a Useful Tool for Managing Diversified Hedge Fund Portfolios”, Hedge Funds Review, 29 May.

Kat, H. M. \& Palaro, H. P. (2005), Who needs hedge funds? A copula-based approach to hedge fund return replication. Retrieved from: https://papers.ssrn.com/sol3/papers.cfm?abstract-id_855424 [Accessed March 2018]

Lee, S. (2014), "The Contribution Risk of REITs in the Blended Public and Private Real Estate Portfolio", Real Estate Finance, Vol. 30, No. 5, pp. 50-55.

Ling, D. C. \& Naranjo, A. (1999), “The integration of commercial real estate markets and stock markets”, Real Estate Economics, Vol. 27, No. 3, pp. 483-515.

Liow, K. H., Ho, K. H. D., Ibrahim, M. F. \& Chen, Z. (2009), "Correlation and volatility dynamics in international real estate securities markets", Journal of Real Estate Finance and Economics, Vol. 39, No. 2, pp. 202223.

Marcato, G. \& Key, T. (2007), "Smoothing and Implications for Asset Allocation Choices", Journal of Porffolio Management, Vol. 33, No. 5, pp. 85-98.

Markowitz, H. (1952), “Portfolio Selection”, Journal of Finance, Vol. 7, No. 1, pp. 77-91.

Morawski, J., Rehkugler, H. \& Fuss, R. (2008), “The nature of listed real estate companies: property or equity market?”, Financial Markets and Porffolio Management, Vol. 22, No. 2, pp. 101-126.

Moss, A. \& Farrelly, K. (2014), The performance implications of adding global listed real estate to an unlisted real estate portfolio: A case study for UK Defined Contribution funds. European Public Real Estate Association.

Moss, A. \& Farrelly, K. (2015), "The performance of a blended real estate portfolio for UK DC investors", Journal of Property Investment \& Finance, Vol. 33, No. 2, pp. 156-168. 
NAREIT (2011), Optimizing Risk and Return in Pension Fund Real Estate: REITs, Private Equity Real Estate and the Blended Portfolio Advantage, National Association of Real Estate Investment Trusts. Retrieved from: www.reit.com/sites/default/files/portals/0/PDF/PortfolioOptimizer.pdf [Accessed March 2018]

O’Doherty, M. S., Savin, N. E. \& Tiwari, A. (2015), "Evaluating hedge funds with pooled benchmarks", Management Science, Vol. 62, No. 1, pp. 69-89.

Oikarinen, E., Hoesli, M. \& Serrano, C. (2011), “The Long-Run Dynamics between Direct and Securitized Real Estate”, Journal of Real Estate Research, Vol. 33, No. 1, pp. 73-102.

Roll, R. (1992), “A Mean/Variance Analysis of Tracking Error”, Journal of Portfolio Management, Vol. 18, No. 4, 1992, pp. 13-22.

Rudd, A. \& Rosenberg, B. (1980), The "Market Model" in Investment Management. The Journal of Finance, Vol. 35, No. 2, pp. 597-607.

Rudolf, M., Wolter, H. J. \& Zimmermann, H. (1999), “A linear model for tracking error minimization”, Journal of Banking \& Finance, Vol. 23, No. 1, pp. 85-103.

Shepard, P., Hobbs, P. \& Liu, Y (2015) Is Real Estate Bond-Like? Growth Drives Long-Run Risk and Return, MSCI. Retrieved from: www.msci.com/www/research-paper/is-real-estate-bond-like-/0182632204 [Accessed March 2018]

Sing, T. F. \& Tan, Z. Y. (2013), "Time-varying correlations between stock and direct real estate returns", Journal of Property Investment \& Finance, Vol. 31, No. 2, pp. 179-195.

Stafford, E. (2017), Replicating Private Equity with V alue Investing, Homemade Leverage, and Hold-to-Maturity Accounting.

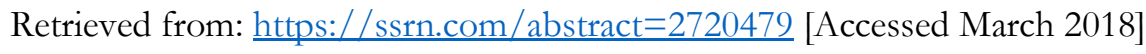

Stevenson, S. (2001), "The Long-Term Advantages to Incorporating Indirect Securities in Direct Real Estate Portfolios”, Journal of Real Estate Porffolio Management, Vol. 7, No. 1, pp. 5-16.

Timmermans, X. (2009), "Investing in illiquid assets", Society of Actuaries: Risks and Rewards, Vol. 53, pp. 12-16.

Tuluca, S., Myer, F. \& Webb, J. (2000), "Dynamics of Private and Public Real Estate Markets", Journal of Real Estate Finance and Economics, Vol. 21, No. 3, pp. 279-296.

Wang, P., Lizieri, C. \& Matysiak, G. (1997), "Information asymmetry, long-run relationship and price discovery in property investment markets", The European Journal of Finance, Vol. 3, No. 3, pp. 261-275.

Yunus, N., Hansz, J. \& Kennedy, P. (2012), "Dynamic Interactions between Private and Public Real Estate Markets: Some International Evidence", Journal of Real Estate Finance and Economics, Vol. 45, No. 4, pp. 10211040. 